\title{
Rights of Children in the Kenyan Primary School Curriculum
}

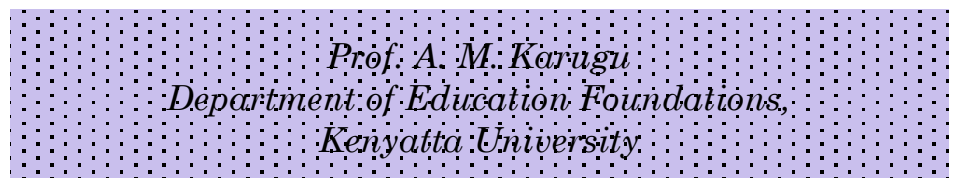

\begin{abstract}
Kenyans today are very conscious and assertive of their rights. They ensured that basic human rights are enshrined in the new Constitution of Kenya 2010 that they passed. Despite all these, it is relevant to question how knowledge about human rights is transmitted and acquired by young Kenyans. We carried out a study in an attempt to provide an answer to this question. Using content analysis method we examined the rights of children as discussed in various social studies text books that are currently used in Kenyan primary schools. The objective was to identify rights of the children, interrogate them as well, as compare and contrast how various authors/ publishers have presented them. In addition, the same method was used to identify and document incidents of violation of children rights as reported in the Daily $\mathrm{Na}$ tion. The major finding of this study is that the social studies curriculum in primary schools as presented in the books that we examined adequately exposes young Kenyans to their rights and related issues. Pupils who suc-
\end{abstract}


cessfully complete primary school course can be viewed to be knowledgeable and aware of their rights. Examining the reported incidents in the Daily Nation however showed that there is still a societal problem in protecting children from abuse. Children are vulnerable and defenseless. Generally, they are not capable of asserting their rights. This is evident, especially, in situations where violators of children rights are people close to them such as parents, guardians and teachers.

\section{Introduction}

A discussion on rights of children often elicits a lot of controversy. Two differing opinions are usually visible in discussions on the topic. On one hand, there are people we may classify as conservatives or traditionalists. They hold strong views that; children have no rights especially in relation to their parents, guardians or other persons who have authority over them. Those who hold this view argue that granting children rights would lead to indiscipline and bad upbringing. Indeed, incidents of child abuse by parents, guardians and teachers have at times been justified on grounds of disciplining a child. A contrary opinion is held by those who may be termed as liberals. In comparison to traditionalists, this group of people argues that children 
have rights. Children rights need to be respected and protected by all in society. The Kenya Government in its pronouncements and actions appears to support this latter view. This is shown by the passing of the Children Act (Republic of Kenya, 2012). The Act is a milestone in consolidating and enhancing children rights in Kenya. The question that needs to be asked is whether children, the beneficiaries of the Act, know their rights as stated not only in the Act, but also in the constitution of Kenya. If the answer is in the affirmative, what is the source of their knowledge? It is in an attempt to answer these questions that we carried out a study, whose findings form the basis of the discussion in this paper.

\section{Method of the Study}

In the first part of the study, we gathered social studies text books approved for use in the teaching of the subject in primary schools in Kenya. We got textbooks from different publishers. There were books from the Jomo Kenyatta Foundation, Longman Kenya Ltd, The Oxford University Press and the Macmillan Kenya Ltd. In the second part of

the study we perused through various issues of the 
Daily Nation newspaper in the year 2012. In this exercise, we were interested in examining newspaper reports on children rights and abuse. We used the content analysis method in examining both the rights of children as presented in the textbooks and as reported in the newspaper.

\section{Children's Rights in Primary School}

\section{Textbooks}

Children rights as a topic in social studies is taught in Kenya primary schools from standard one to standard eight. Our objective in studying the social studies text books was to examine how the authors have presented the topic to the learners in various classes. A challenge faced by the authors of the social studies text books is that of defining the concept of rights to learners in lower primary. Children at this level have limited mastery of the English language. The problem of mastery of the language may be more acute in rural, than in urban schools where English is not the medium of instruction in lower primary. In summary, authors of these books have some difficulty in simplifying legal language to be easily understood by learners in lower primary. 
In the text book, Primary Social Studies Pupils Book One, published by the Macmillan Kenya Ltd., the topic is found in a unit three - "Our Family Needs and Children Rights" (Sanya, Njuguna \& Nyaga, 2003). On page thirty five, the authors pose a question. Why do children have rights? This appears to be a rhetorical question since the authors do not provide an answer. They define a right as freedom to some things. There is a caution that is usually given on enjoyment of one's freedom. The freedom to enjoy our rights should not infringe on the freedom of others. The word infringe is difficult for standard one pupils. In the absence of a better word, the authors have written that freedom to some things should not make others unhappy (Sanya, et al., 2003:35). This explanation stretches the meaning of the word infringe. One can simply be unhappy with someone without one's freedom being infringed. The authors further state the following three children rights: The right to go to school, the right to be with friends and freedom to choose toys and games. In addition, they have stated things that children should not do, thus: work for money, be sent to sell some things, and be forced to marry, smoke, sniff glue or drink alcohol. 
Furthermore, standard two text, books published by the following four different publishers were examined: Jomo Kenyatta Foundation Kenya, Longman Kenya, Longhorn Publishers and Oxford University Press. The standard two book published by the Jomo Kenyatta Foundation, discusses the topic of child rights in unit seven. The book starts the discussion by revising the rights as they were presented in book one. These are: rights to a name, primary education, play and rest, worship and parental care, food and health. In addition, there are rights to: protection from child labour, to life and protection from drugs. However, other rights mentioned in this text book need some discussion and elaboration to avoid misinterpretations. We point out a few here; the right for a child to express his or her feelings - The authors are not specific on the feelings they have in mind. This right could easily be misinterpreted unless it is qualified. There are certain feelings, for example, sexual; one that children are not expected to express till they reach adulthood. The right for a child to live with parents; a child is quite helpless in invoking this right. What can a child do, if his or her parents decide to divorce, is orphaned by war or death of parents? The right to be treated equally despite his/her gender. Economic and cultural factors lead to discrimi- 
nation of children based on their gender. Finally, the authors of the book have stated that every child has a right to be protected from harsh punishment. It is not clear what they mean by harsh punishment. The authors ought to have given a few examples of what they take as harsh punishment. This would help children in invoking this right. (Jomo Kenyatta, 1988).

It is also in book two that the concept of child abuse is introduced. The authors discuss it in the context of the home and the school. They define child abuse as, simply, not observing the rights of the child at home. It can be done by the parents, brother or other members of the family. Examples of child abuse at home include: children are not allowed to go to school, children are forced to do difficult jobs, and they are not allowed to complete their education especially girls who are also married early in some communities. Other type of child abuse at home identified by the authors is punishment given to children mostly by parents. The authors observe that children are at times given very harsh punishment at home. They define harsh punishment as beating, burning hands and other parts of the body. Other forms of harsh punishment are: refusing to give children food, locking them out of 
the houses at night and locking disabled children in the house for long periods.

The authors identify and discuss forms of child abuse that commonly occur in schools. One of the most common forms of child abuse found in schools is bullying. Some child bullies may force other children to do things for them. In some schools bullying of fresher's has been institutionalized. If bullying is discouraged in primary schools it can be eliminated altogether in the secondary schools where, in some of them, it has become an accepted way of welcoming form one students. Another common example of child abuse in schools may be attributed to teachers. Teachers abuse children by using bad language and also giving children harsh punishment. The authors have, however, cautioned teachers not to punish children harshly.

The second book that we examine is the one published by Longman Kenya Ltd. The authors discuss the rights of the child in unit seven entitled "Child Protection" (Galgalo, Owich, Ogomo \& Mwaniki, 2009). In what appears to be answer to the question - Why should children have rights? the authors have stated that child rights protect 
children from bad things and help them grow well. Like other authors discussed above, they do not define what they mean by bad things. They have, however, broadened the range of children rights by, including the right to be heard and the right to clean environment.

In addition, the authors have discussed child abuse under the same unit. They have attempted to define child abuse by giving an example of a child who is badly beaten at home. At times the beating may cause injury to a child. This is what the authors term as child abuse. We found some of the examples of child abuse that the authors give, somehow, overstretched. For example, failing to teach children in school is denying them the right to education and this according to them is child abuse. Another example where a teacher is shown outside a classroom talking to another teacher. The consequence is that the class/children miss a lesson. The authors state that teachers should teach all lessons. Failing to teach, according to the authors, is denying children the right to education. This is child abuse (Galgalo, Owich, Ogomo \& Mwaniki, 2009).

The third book we examined is pupil's book two published by the Longhorn Publishers 
(Kanjoya \& Ogula, 2003). The approach of this book is different from the others. The authors use pictures to converse the concept of children rights. In the picture, children are shown visiting an Aunt Mrs. Ali. They ask her to tell them about child rights. It is a question and answer session. Children ask Mrs. Ali - what is a right? She answers - A right is a claim to something. It is not clear whether children in standard two understand the meaning of the word claim as used here. It would also have helped if the authors had qualified this definition by pointing out that a claim has a limit. One cannot claim what does not belong to them. The authors discuss types of child abuse using photographs. In defining child abuse they have written - some people treat children badly - this is called child abuse. Although they have given child labour as an example of child abuse we think they still needed to have gone further and demonstrated what they mean by a child being treated badly.

The fourth book that we examined was Our Lives Today: Social Studies Pupil's Book Two by Cephas C. Kamau, Maryclaire Indire and Gideon M. Ombongi published by Oxford University Press. The authors of this book define rights of the child in very broad terms. They assert - "there are things 
that children must have in order to grow well". The authors call these things rights of children. (Kamau, Indire and Ombongi, 2009:65). It is from this definition that they proceed to show the various rights of the child. In regard to child abuse, they define it in terms of signs. They observe that when some bad things are done to children these are signs of child abuse. For example, when parents beat their children very hard. It is not, however, clear what they mean as beating very hard.

In upper primary, the topic "Child Rights" changes to "Human Rights and Democracy". We examined this in standard five, six and seven text books. For instance, in the book, Living together: Social Studies Standard 5 by Eve Galgalo, G Owich, C. Ogomo and C. Mwaniki (2009) published by Longman Kenya Limited, the authors restate the rights of the child. They define child abuse as denial of child rights. Furthermore, they upgrade the discussion of children rights from that of lower primary by stating that one may protect children from abuse by respecting child rights. Additionally, one may report to the children department, religious leaders, police, teachers and parents cases of child abuse. They have not, however, discussed some of the difficulties a child may experience in 
reporting abuse. It may prove difficult for a child to report incidents of abuse especially where their abusers are parents, guardians or teachers. In situations where protectors, become culprits and violators of the same rights that they are expected to defend, children may not know what to do simply because they are afraid of the consequences of reporting, parents, teachers or guardians.

In standard six pupils book, Living Together: Social Studies Standard 6 bye Eve Galgalo, G. Owich, C. Ogomo and C. Mwaniki (2009), published by Longman Kenya Limited, the concept of human rights are also is elaborated comprehensively than in standard five. The writers state that human rights are also called basic rights. These rights are based on values which favour human dignity, that is, what makes a person a human being. They point out that the government does not give rights. All persons are born with these rights. The role of the government is to ensure that every person enjoys certain rights and protects people against human right abuse. In a further attempt to clarify the concept, the authors have classified human rights into three categories: Civil and political rights, social and economic rights, environmental, cultural and developmental rights. Apart from the 
categorization, the authors do not discuss or give examples of these rights. It would have been useful to both teachers and pupils if some common examples of each category had been given in order to trigger discussions among children and their teachers on various categories of human rights.

In the standard seven pupils book, Living Together: Social Studies Standard 7 by C. Ogomo and Savani, (2009), published by Longman Kenya Limited, the authors continue with the discussion on "Democracy and Human Rights". They explain in more detail, than in standard six, the relationship between democracy and human rights. In this book, they have pointed out that without democracy and human rights, society cannot work. They have also discussed abuse of human rights and given examples such as wrongful confinement, wrongful arrest and denying one a chance to go to school. It is important to note some of the abuses are, at times, committed by officers or organs of the State. Although the authors do not point this out, the fact that they have given such examples as wrongful arrest, wrongful confinement and others, is sufficient evidence of the democratic space that has been created in Kenya in the recent past. In the same breath the authors also discuss the importance of respecting human rights. 
From the above examination of Social Studies Text books, it is clear the issue of children rights is satisfactorily covered in the primary school curriculum. A child who has completed primary school, successfully, may therefore, be expected to have basic knowledge of their rights. Equally, such a child has also been exposed to knowledge of child abuse. If children have the knowledge of their rights and how they are abused, what are the challenges confronting them? The challenge lies in the fact that children may have the knowledge of their rights but are still vulnerable and defenseless. They are unable to assert or demand their rights. They are in most cases helpless in regard to people such as parents, guardians and teachers who instead of being protectors, may sometimes, turn out to be the greatest violators' of children rights. In case of parents the issue becomes more complex in situations where the rights of the parents is comparison with those of the child are not clearly demarcated. What is the right of a parent over their child, especially in regard to punishment?

Is this right absolute or limited? In the second part of the paper we examine incidents of child abuse by parents as reported in the Daily Nation. The intention, here, is to argue that we need to go 
beyond equipping children with mere knowledge about their rights. There is a need for more to be done to ensure that children rights are not abused by parents, and that they are respected and protected.

\section{Reports of Child Abuse in the Daily Nation Newspaper in 2012}

There are many cases of violation of children rights and child abuse that occur daily, but remain unreported. Some of the reports found in the daily newspapers show that there is a significant violation of children rights by parents and teachers. Parents and teachers are persons whose roles, on a daily basis, put them in close contact with children. For the purpose of this paper, we examined the reported cases of child abuse by parents. We examined two types of child abuse cases attributed to parents that were highlighted in reports by Daily Nation in the year 2012. One type is in regard to cases associated with severe punishment, especially beating, meted out by parents on their children. The second type is cases associated with parents' religious beliefs. Some parents have been reported of denying their children medical care because their faith does not allow taking the sick to hospital. We examined these two types of cases to demonstrate the weakness and 
helplessness of a child in a situation where a parent is a child abuser. The first report that we examined is that associated with severe punishment of children mainly, beating.

Mr. Benjamin Cheruiyot and his wife Ruth from Chepterit village, Nandi County beat their daughter, Olivia Chepkirui, to death between $9^{\text {th }}$ and $10^{\text {th }}$ June, 2012. Olivia was a standard eight pupil at Kongwal Primary school where she was registered to sit for her Kenya Certificate of Primary Examination, (KCPE) later in that year. The reason why the parents beat her to death is that her father had found her intimate in bed with her teenage lover and neighbour, 17 year old Moses Kipkemboi. The two parents were charged with murder of their daughter. Ruth was released after their lawyer successfully argued that she was not involved in the killing. The charge against Benjamin was reduced to manslaughter and he pleaded guilty. On June 27, Benjamin appeared before Justice Festus Azangalala. He was locked up for a day. While Benjamin welcomed the judgment since he had expected a long jail term, it was received with shock and indignation in some quarters. Public opinion remains sharply divided on the issue. (Daily Nation, June 29, 2012) 
On one hand, there were people and groups opposed to the judgment and who called the Chief Justice to order a retrial of the case. On the other hand, there were those who supported the judgment arguing that the judge's rulings were within normal principles of law. This latter position was especially expressed by the North Rift Chapter of the Law Society of Kenya. Mr. James Njuguna, the spokesman of the chapter argued that 'disciplining a child is part of the parental correctional duty, but it was unfortunate that Olivia died in the process' (Daily Nation, July, 9, 2012). According to Njuguna, the judge was fair in the ruling, considering that the father demonstrated his remorsefulness for killing his daughter in the process of disciplining her.

Those opposed to the ruling were mainly members of civil society groups. They argued that one day sentence undermined the value of human life, noting that it was likely to encourage other parents to abuse their children in the pretext of disciplining them. Nick Omito of the Centre for Human Rights and Democracy observed that "no one has the right to kill, even when wronged, and the sentence would set a bad precedent to other parents' (Mazera \& Tom, 2012). There is little dispute that parents have a responsibility, indeed a duty, to discipline 
their children. The recurring debate, however, has been the extent to which a parent can go in disciplining an errant child? What should be the type and form of parental discipline? Should it be caning, denying a child food, locking a child out of the house or what? Should a parent spare the rod and spoil the child? This is the dilemma that faces parents as well as the general public in the debate on discipline. Though it is widely agreed that discipline is essential for the wellbeing of society there is little consensus on the form and type of disciplining children.

We have seen how the authors of the text books, examined above, in order not to be drawn into the controversy on child discipline have avoided providing direct answers to the questions associated with the issue. They have, for example, written vaguely that parents should not punish children harshly or beat them badly. We consider this vague and avoiding the issue since the authors have not indicated what they would regard as harsh punishment or bad beating.

The second type of punishment that attracted headlines in the Daily Nation is that of parents who, because of their religious belief, denied 
children medical care. Refusing to take a sick child to hospital is an offence under the Kenyan laws. We examined cases reported by the Daily Nation of parents arrested and taken to court for denying their children medical care. Majority of parents prosecuted for committing the offence are members of a church known as Kanitha Wa Ngai (Church of God). Members of this church refuse to take children for immunization or treatment for a disease. They believe healing comes through prayers. Another church that holds and propagates the same beliefs is the Holy Ghost Church of East Africa. Interestingly, the two churches are found in Nakuru County. In July a Mr. Macharia a member of the Holy Ghost Church was charged, in a Njoro court, with failing to seek medical care for his two children. According to the police, two of Mr. Macharias children, one of them aged one and half years and the other nine months, died in June, 2012 after falling ill. The children's deaths were attributed to the fact that their father, Mr. Macharia, did not bother to seek medical assistance for them when they fell sick. Mr. Macharia was arrested when he went to get a burial permit from his local chief. At the same time, it was also discovered that apart from the dead children, Macharia had two other children who were sick at home. In the court the judge gave 
Macharia two options. He was asked to choose between remaining in remand and taking his children to hospital. Mr. Macharia preferred remaining in remand to taking his children to hospital.(Daily Nation, July 4, 2012). According to him, people should only rely on faith to either keep diseases at bay or die. He stated that 'to get sick, to be well or to die are all the will of God'. The Holy Ghost Church's teaching against seeking medical attention is based on the Book of Exodus. In Exodus 20, the children of Israel were cautioned against worshipping idols. Going to hospital and seeking treatment from a doctor is, according to the followers of this church, synonymous with worshipping the doctor (Daily Nation, July 4, 2012). We narrate the following case of Margaret Nduta, a member of Kanitha Wa Ngai, to show the extreme fanaticism of the followers of the above mentioned two churches.

Margaret Nduta had defied a court order to take her baby to hospital. As a result she was forced to do so under prison officers' escort. She was taken to Nyahururu District Hospital to have her one year-old daughter examined. What is shocking about this case is that Nduta refused to give even slightest assistance to her sick child. She declined 
to hold the baby as the doctor examined her. She protested that her faith did not allow the use of drugs to heal diseases. (Daily Nation, September 14, 2012). Nduta was cautioned by the court to stop using her daughter's condition to discredit the immunization offered by the government free of charge. She was reported to have told other breast feeding mothers that her daughter's condition worsened after she was immunized and that she feared that the girl might never walk. It was this malicious romour, spread by Nduta, which had prompted the court to demand a medical report on the child's health, (Daily Nation, September 14, 2012). Nduta had six other children who were under eighteen years old. The Nyahururu Children Officer pleaded with the court not to give Nduta a custodial sentence since her children stood to suffer. Here lies the dilemma. What to do with a mother like Nduta, who has several children, and, cannot be jailed because of not giving medical care to one sick child since the rest of her other children are likely to suffer in the process. 


\section{Conclusions}

In this paper, we set out to examine the rights of children as presented in the Kenyan primary school social studies textbooks. From our findings it is evident children are sensitized about their rights from an early age. The topic is introduced, for the first time, in standard two. Majority of children in this class are usually eight years old. The fact that the topic is covered in the social studies syllabus of standard two to eight is evidence to show that children who complete the primary school course in Kenya have been exposed, sufficiently, to issues regarding their rights. What is not clear is whether this exposure or awareness is enough to make them demand, assert, claim or defend their rights. A general observation derived from this study is that children are broadly weak and afraid to assert their rights against parents and teachers. Children rights are prone to abuse in day to day interactions with parents, guardians and teachers. A child may be abused in this interaction and may remain silent. If sometimes silence in such situations is noticed it should not be taken to mean the abused child does not know his or her rights. Instead, silence on the part of the victim could be attributed to the fact that a child has 
to submit to those who have been put over him or her in order to survive.

In the last part of the paper we have discussed the examples of violation of children rights by parents through severe beating. We have discussed the public debate which followed the case of the parent who beat his daughter to death. We have also cited cases where children have been denied medical care because their parent's religious believes are against taking the sick to hospital. These incidents which were reported by the Daily Nation newspapers in 2012 are just a tip of the iceberg. There might be many other cases which go unreported or do not come to the attention of the public. This is because most cases of child abuse occur in confined places such as homes or classrooms where children are at the mercy of either parents or teachers. Children officers are state employees who are expected to investigate and prosecute offenders of children rights. This cadre of people could play a very important role in sensitizing the public on children rights. They are, however, rarely seen, heard or even known in most parts of Kenya. Few children, when abused, would have the courage to report to the police. Police officers are generally feared and children tend to run away 
from them. Despite these shortcomings, this study has shown that efforts have been made through the primary school curriculum to create knowledge and awareness of children rights. However, there is a need to strengthen the school efforts by educating the general public about the importance of observing and protecting children rights. 


\section{References}

Daily Nation, (2012, June 29). A travesty of justice has been committed. Editorial page.

Galgalo, E., Mwaniki, C., Ogomo, C., \& Owich, E. (2009). Living together: social studies pupils book 2 . Nairobi: Longman Kenya Ltd.

Galgalo, E. (2009). Living together, social studies pupils' book 5. Nairobi: Longman Kenya Ltd.

Galgalo, E. (2009). Living together, social studies pupils 6. Nairobi: Longman Kenya Ltd.

James, K. \& Rachel. (2012, September 14). Court pushes sect woman to take her child to hospital under security. Daily Nation, p.32.Nairobi.

Jomo Kenyatta Foundation. (1988). Social studies pupils book 2. Nairobi: JKF.

Kamau, C. C. (2009). Our lives today, social studies pupils' book 2. Nairobi: Oxford University Press.

Kanjoya, J. \& Ogula, P. (2003). Comprehensive social studies, pupils book 2. Nairobi: Longhorn Publishers.

Mazera, N. \&Tom, M. (2012, July 9). He got eight hours in jail for killing his daughter. Daily Nation, 
p.DN2. Nairobi.

Ogomo, C. \& Zavani, P. (2009). Living together, social studies pupils book 7. Nairobi: Longman Kenya Ltd.

Rachel, K. (2012, July 4). Court turns to bible in neglect case. Daily Nation, p.30. Nairobi

Republic of Kenya, (2012). The children act, 2001. Nairobi: Government Printer.

Sanya, A., Njuguna, L, \& Nyaga, A. (2003). Primary social studies pupils book 1. Nairobi: Macmillan Kenya Ltd. 